\title{
Economic and Biological Features of the Holstein Cows Selected in Hungary when Year-Round Stable System
}

\author{
Tunikov Gennadiy Mikhaylovich ${ }^{1}$, Morozova Nina Ivanovna ${ }^{2}$, Musaev Farrukh Ataullakhovich ${ }^{3}$, Lebedev \\ Vyacheslav Ivanovich ${ }^{4}$, Ivanova Larisa Vasilyevna ${ }^{5}$, Muravyeva Yuliya Sergeevna ${ }^{6}$ \\ ${ }^{1}$ Doctor of Agricultural Science, Professor of the Faculty of Animal Science and Biology, Ryazan State Agrotechnological University, \\ Ryazan, Russia \\ 390044, Russia, Ryazan, Kostychev Str., 1 \\ ${ }^{2}$ Doctor of Agricultural Science, Head of the Faculty of Technologies of Agricultural Production and Processing, Professor, \\ Ryazan State Agrotechnological University, \\ Ryazan, Russia \\ 390044, Russia, Ryazan, Kostychev Str., 1 \\ ${ }^{3}$ Doctor of Agricultural Science, \\ Professor of the Faculty of Technologies of Agricultural Production and Processing,Ryazan State Agrotechnological University,Ryazan, \\ Russia \\ 390044, Russia, Ryazan, Kostychev Str., 1 \\ ${ }^{4}$ Scientific Director of the Institute, Chief Researcher, Doctor S. - H. Sciences Federal State Budgetary InstitutionResearch Institute of \\ Apiculture \\ Ryazan oblast, Rybnoye, Post 22, \\ ${ }^{5}$ Chief Zootechnician and Stock Breeder,JSC "AgroCapital”, Ryazan oblast, \\ ${ }^{6}$ Senior Teacher of the Faculty of Public CateringRyazan State Agrotechnological University, Ryazan, Russia \\ 390044, Russia, Ryazan, Kostychev Str., 1
}

\begin{abstract}
The purpose of the work is to study economic and biological features of the Holstein cows selected in Hungary when year-round stable system in conditions of the reconstructed dairy complex. Economic characters of purebred Holstein cows of Hungarian selection were studied (86 animals). The diets of cows were formed using the ASP program. Feeding control was carried out on the biochemical parameters of cows' blood. Hematological parameters of blood: leukocytes, erythrocytes and hemoglobin were determined with hematology analyzer XT-2000i from Sysmex. Total protein in blood serum (by biuret reaction), albumins and globulins, and bilirubin were determined with photocolorimeter KFK-2. The content of glucose and cholesterol in the blood was determined with the help of a biochemical automatic analyzer. Blood enzymes: ALT and AST were determined by the Reitman-Fraenkel method. Lactation yield and milk quality of cows were studied by the first three lactations, depending on the genealogical affiliation on three lines: Montvik Chiftain 17 heads; Vis Beck Idiala - 50 heads and Reflection of Sovering - 19 heads. To study the lactation performance of cows, information recorded in computer base "SELEX", functioning at the farm, was used. The intensity of milk ejection was considered with the help of "Dairymaster" program. The physical-chemical parameters of Holstein cows' milk were studied in the second lactation. The following parameters were determined in milk: density, acidity, freezing point, heat resistance, purity, fat weight fraction, protein, lactose and SOMO. Milk quality parameters were determined with the help of ultrasonic device "Ecomilk-M". In addition to the above parameters, the presence of antibiotics and the number of somatic cells were determined in the commercial milk. Holstein cows of the Hungarian selection had economic and biological features due to age and genealogical affiliation. The maximum milk yield for three full lactations was obtained from cows of the Vis Beck Idiala line - 20,881 kg of milk. In comfortable conditions of keeping and feeding, the Holstein cattle of the Hungarian selection realized the genetic potential: in terms of milk yield by $86.1-98.6 \%$, in the fat weight fraction by $102.7-$ $108.4 \%$ and in protein weight fraction by $95.2-104.9 \%$.
\end{abstract}

Keywords: Holstein breed, cows, Hungarian selection, year-round stable system, lactation performance, milk quality.

\section{Introduction}

In dairy cattle breeding of many countries of the world, the highly productive Holstein breed takes the leading position. Animals have high lactation performance, good adaptability to industrial conditions of housing and milking. Cows have high growth, large live weight, a well-developed bath-shaped udder, with the same development of dairy lobes and a high milk flow rate. Holstein cattle is the result of long-term breeding work and is in demand in many countries of the world $[9,11,12]$.

Under conditions of loose housing and balanced feeding, the milk yield of Holstein cows in the pedigree herds of the Russian Federation reaches $8,000-10,000 \mathrm{~kg}$, and the average milk yield of 
Holstein cows in commodity farms is at the level of 6,000-7,000 $[1,5]$.

In recent years, many countries of the world have paid much attention the development and creation of a new model of selection and breeding work that optimally combines high lactation performance, reproductive qualities, productive longevity of cows and profitability. The breeding programs of the USA, Canada and Holland have new signs: fertility, lifetime profit index and profitability index $[8,13,16,17,18,19,21,22,24,31]$.

The modern dairy livestock differs in its economic and biological parameters from the black-and-white type of European countries [25-28].

The cows of the American-Canadian type have distinctive features in the exterior and constitution. When adapting highly productive Holstein cattle, the biological characteristics of animals, housing conditions, feeding and microclimate should be taken into account. There are three adaptation factors: selection, stress resistance, anti-stress prevention and therapy [2, 3, 4, 23, 29, 30]. With the year-round loose housing of Holstein cows, such economic characters as lactation performance, disease resistance, strength of constitution, suitability for machine milking and productive longevity are of prime importance. An important factor in breeding Holstein cattle is the technology of housing, it should be as close as possible to the biological needs of animals. It is necessary to create conditions of increased comfort for keeping cows and provide animals with high-quality feeds in accordance with the physiological condition $[12,16,17]$.

The aim of the investigation is to study the economic characters of the Holstein breed cows of the Hungarian selection with yearround housing.

The investigation tasks are as it follows:

- justifying the technology of the cows' year-round loose housing;

- studying the feed base and technology of cows' feeding to realize the genetic potential;

- analyzing the technology of milking and primary processing of milk in milking parlor "Dairymaster Milk Manager";

- studying the economic characters of the Holstein cows of the Hungarian selection;

- studying the lactaion yield and milk quality of cows, depending on the genotypic and phenotypic factors;

- determining the economic efficiency of milk production of Holstein cows of the Hungarian selection with year-round stable system.

\section{Materials and Methods}

Experimental studies took place in the conditions of the dairy complex of the breeding reproducer of Ryazan oblast. Experimental animals were kept at the dairy complex with a straight-line sectional system of milk production. The conditions of housing and feeding the experimental cows were the same and met the existing requirements.

The economic characters of purebred Holstein cows of the Hungarian selection were studied ( 86 animals). The rations for feeding the cows were in the "Feed rations" program. Zootechnical analysis of fodder was performed in the feed laboratory of Lukhovitsky district in Moscow oblast.

Feeding control was carried out on the biochemical parameters of blood of cows. Blood was collected from the jugular vein before feeding (3 animals from each group). Such hematological parameters of blood as leukocytes, erythrocytes and hemoglobin were determined with the help of hematology analyzer XT-2000i from Sysmex. Total protein in the blood serum (by biuret reaction), albumins and globulins, as well as bilirubin were determined with the help of photocolorimeter KFK-2. The content of glucose and cholesterol in the blood was determined with Statfax 1904 and a biochemical automatic analyzer. Such blood enzymes as ALT and AST were determined by the ReitmanFraenkel method.
Lactation yield and milk quality of cows were studied by the first three lactations taking into account the genealogical origin: Montvik Chiftain - 17 heads; Vis Beck Idiala - 50 heads and Reflection of Sovering - 19 heads. The lactation performance of cows was studied in the system "SELEX", functioning at the farm, and the intensity of milk ejection was taken into account according to program "Dairymaster".

The composition and physical-chemical properties of milk were studied by the following parameters: density, acidity, freezing point, heat resistance, mass fraction of fat, protein, lactose and SOMO. Milk quality parameters were determined using ultrasonic device "Ecomilk-M".

Experimental data were processed by the method of mathematical statistics for N.A. Plokhinskiy, 1969 and E.K. Merkuryeva, 1970 using the standard package of statistical analysis Microsoft Exsel2007.

\section{Results}

Milk production at pedigree breeding unit JSC "AgroCapital" is carried out in the dairy complex, reconstructed for loose housing of cows throughout the year. The dairy complex is divided into production workshops: increasing the milk yield and insemination from 1 to 90 days; milk production from 91 to 305 days; dry cows (60 days); maternity barn (10 days); milking parlor; primary milk processing; veterinary clinic in the maternity barn; information center for process control (selection, feeding, milking and primary processing of milk).

The reconstruction of the dairy complex for 400 cows allowed the introduction of a continuous-flow sectional milk production system, the establishment of production workshops and the modernization of milk production technology. High-tech equipment with the milking parlor of the Irish company "Dairymaster" has been introduced into production.

Selection and breeding work with the herd is carried out in the information program "Plinor". The farm breeds purebred Holstein cattle, imported from Hungary and the Netherlands. The main method of cattle breeding is purebred: along lines and families. The method of genetic markers is used in breeding work. The animals mainly belong to three genealogical lines: Vis Beck Idiala, Montvik Chiftain and Reflection Sovering. The improvement of the breeding and productive qualities of the breeding stock is carried out by individual fixing the bullsimprovers, assessed by a complex of characteristics and the quality of the offspring. The semen of bulls is imported from the Federal State Unitary Enterprise "Central Station for Artificial Insemination of Farm Animals" (FSUE CSAI), JSC "Moscowskoe" for breeding work and from abroad.

The lactation performance of the best Holstein cows selected for the mothers of bulls is at the level of 9-10 thousand $\mathrm{kg}$ of milk and more. The fat content in milk is more than $4.0 \%$ and the protein content is more than $3.2 \%$.

To prepare rations, cows of the dairy herd are divided into four technological groups. The first group consists of fresh calves with a yield of between 35 and $30 \mathrm{~kg}$ per day, the second group gives $30-25 \mathrm{~kg}$, cows of the third group give $25-20 \mathrm{~kg}$ and those of the fourth group are down-calving ones. Particular attention was paid to the diets of cows for increasing the milk yield in the period from 10 to 90 days of lactation. In the winter period the diet included hay, vetch-oat silage, corn silage, mixed fodder K 60-189 for lactating cows (granulated), mixed fodder K 61 from 6000 (crumbled), sunflower cake, crystalline glucose, selplex, premix, rumimax, salt and fodder chalk. In the summer period, the main feed in the ration of cows was the herbage of milk-wax maize and green forage. The fodders were crushed to a length of 5-7 cm with the help of feed mixer IRSK 12 "Master" and distributed to feed tables twice a day.

Monitoring the full value of feeding was carried out on the biochemical parameters of the blood of cows increasing the milk 
yield. According to the results of studies, the reserve alkalinity was 43.7-37.0 vol. \% CO2 at the rate of 40 vol. \% CO2, the total protein ranged from $7.9 \%$ to $9.0 \%$ at the rate of $7.0 \%$, calcium was at the level of $11.4-10.2 \mathrm{mg} \%$ at the rate of $9.0 \mathrm{mg} \%$ and phosphorus was at the level of $6.4-5.9 \mathrm{mg} \%$ at the rate of $5.0 \mathrm{mg}$ $\%$.

The enzymatic activity of the blood of cows was within the physiological norm or exceeded it. The content of AST was $1.5 \pm$ $0.11 \mathrm{mmol} / 1(+0.3)$ and that of ALT was $1.6 \pm 0.2(+0.5)$. Alkaline phosphatase was at the level of $1.7 \pm 0.09$ baud. The content of alpha-amylase was $56 \pm 16.4$ units at the rate of 8-32 units.

Consequently, in the period of maximum productivity in Holstein cows of the Hungarian selection, an increased content of enzymes was observed in the serum, which indicated the intensity of mineral, protein and carbohydrate metabolism.
Economic and biological features of Holstein cows of the Hungarian selection. The primary parameter of dairy cows' productivity is live weight. Live weight is the most important feature of cattle breeding, affecting the lactation performance of cows and characterizing their development.

However, analysis of the vast array of animals in the Nordic countries showed that the cows' weight does not have any positive effect on their productivity due to the fact that large animals consume more feed to maintain their own life activity [9].

The results of our investigations have shown that cows in the third lactation had the maximum live weight. The animals of the Reflection of Sovering line are $568.7 \mathrm{~kg}$, which is $17.1 \mathrm{~kg}$ or $3.1 \%$ more as compared to the animals of the Vis Beck Idiala line and $3.4 \mathrm{~kg}$ or $0.6 \%$ as compared to the Montvik Chiftain line (Table $1)$.

Table 1: Economic and biological features of cows, depending on the genealogical affiliation

\begin{tabular}{|c|c|c|c|c|c|c|}
\hline Lactation & Age of $1^{\text {st }}$ calving & Live weight, $\mathrm{kg}$ & $\begin{array}{c}\text { Milk ejection } \\
\text { intensity, } \mathrm{kg} / \mathrm{min}\end{array}$ & $\begin{array}{c}\text { Service-period, } \\
\text { days }\end{array}$ & Dry period, days & $\begin{array}{c}\text { Lactation stability } \\
\text { coefficient }\end{array}$ \\
\hline \multicolumn{7}{|c|}{ Vis Beck Idiala line $(n=50)$} \\
\hline First & $25.4 \pm 0.38$ & $519.2 \pm 3.4$ & $1.12 \pm 0.2$ & $152.4 \pm 10.4$ & - & $90.1 \pm 1.6$ \\
\hline Second & - & $530.8 \pm 2.3$ & $0.93 \pm 2.3$ & $147.4 \pm 14.2$ & $52.7 \pm 1.3$ & $92.4 \pm 2.3$ \\
\hline Third & & $551.6 \pm 9.0$ & $1.71 \pm 0.1$ & $157.2 \pm 16.4$ & $58.5 \pm 4.0$ & $98.8 \pm 1.9$ \\
\hline On the average & & & $1.25 \pm 0.9$ & $152.3 \pm 14.0$ & $55.6 \pm 2.7$ & $93.8 \pm 1.9$ \\
\hline \multicolumn{7}{|c|}{ Montvik Chiftain line $(\mathrm{n}=17)$} \\
\hline First & $25.8 \pm 0.56$ & $523.8 \pm 6.2$ & $1.44 \pm 0.3$ & $207.4 \pm 20.7$ & - & $86.5 \pm 1.9$ \\
\hline Second & - & $538.4 \pm 3.9$ & $1.44 \pm 0.3$ & $185.4 \pm 24.3$ & $56.02 \pm 2.4$ & $92.5 \pm 2.6$ \\
\hline Third & - & $565.3 \pm 12.0$ & $1.76 \pm 0.07$ & $185.7 \pm 21$ & $63.7 \pm 5.7$ & $96.7 \pm 3.0$ \\
\hline On the average & & & $1.55 \pm 0.22$ & $192.8 \pm 22.0$ & $59.9 \pm 4.0$ & $91.9 \pm 2.5$ \\
\hline \multicolumn{7}{|c|}{ Reflection of Sovering line $(\mathrm{n}=19)$} \\
\hline First & $25.5 \pm 0.70$ & $516.1 \pm 3.4$ & $1.2 \pm 0.3$ & $184.6 \pm 31.3$ & - & $91.7 \pm 2.6$ \\
\hline Second & - & $557.4 \pm 8.9$ & $1.2 \pm 0.3$ & $147.9 \pm 23.1$ & $55.8 \pm 3.3$ & $93.7 \pm 2.1$ \\
\hline Third & - & $568.7 \pm 8.9$ & $1.63 \pm 0.08$ & $137.4 \pm 13.8$ & $60.8 \pm 3.0$ & $96.1 \pm 1.0$ \\
\hline On the average & & & $1.34 \pm 0.23$ & $156.6 \pm 23.0$ & $58.3 \pm 3.2$ & $93.8 \pm 1.9$ \\
\hline
\end{tabular}

Note: * - The results are reliable with $\mathrm{P} \geq 0.95 ; * *-\mathrm{P} \geq 0.99$; *** $\mathrm{P} \geq 0.999$. The duration of the interlactation period was within the physiological norm and was 52.7-63.7 days. The duration of the service period for Holstein cows of the Hungarian selection was relatively high and was within 152.3-181.5 days, the minimum duration was for animals of the Vis Beck Aidiala line - 152.3 days.

The intensity of milk ejection was at the level of $0.93-1.76 \mathrm{~kg} /$ min and increased from the first lactation to the third one by 0.32 $0.59 \mathrm{~kg} / \mathrm{min}$ or by 26.6-34.5\%. Over the course of three lactations, cows belonging to the Montvik Chiftain line had the best intensity of milk ejection equal to $1.55 \pm 0.22 \mathrm{~kg} / \mathrm{min}$.

The exterior evaluation was carried out on basic measurements characterizing the growth and development of animals. The study of exterior measurements of the Holstein cows showed that they increased with age from the first lactation to the third one. Thus, the height at the withers of the cows in the first lactation was within 138.2-140.4 cm, an average of $138.7 \pm 0.2 \mathrm{~cm}$, and in the third lactation, this parameter increased by $5.7 \mathrm{~cm}$ or $4.1 \%$ and was $144.4 \pm 0.2 \mathrm{~cm}$. Significant differences depending on genealogical affiliation were not found.

The daughters of the bulls of the Montvik Chiftain line had the maximum slanting length of the body in all three lactations - 173.2 $\pm 0.9-177.9 \pm 1.3 \mathrm{~cm}$.

The daughters of the bulls of the Reflection of Sovering line had the maximum girth of the breast behind the shoulders, $192.0 \pm 1.0$ $193.3 \pm 1.2 \mathrm{~cm}$, in the second and third lactations.

Based on the studies, we found that the Holstein cows of the Hungarian selection had exterior characteristics due to the age and genealogical affiliation of the cows. Animals belonging to the
Reflection of Sovering line had the best commercial-biological traits.

The lactation performance of the Hungarian cows increased from the first to the third lactation by $1156-1419 \mathrm{~kg}$ or by $19.7-25.4 \%$. The maximum increase in milk yield on average for three lactations was given by Reflection of Sovering cows - $1419 \mathrm{~kg}$ or more that was $25.4 \%$ higher as compared to the milk yield from the first lactation (Table 2).

A comparative evaluation of the lactation performance of cows, depending on their genealogical affiliation, showed that the maximum lactation performance was obtained from cows of the Vis Beck Idiala line: for the third lactation - $7034 \mathrm{~kg}$ with fat content of $3.99 \%$, the average yield of three lactations - $6373.7 \mathrm{~kg}$ and the milk ratio was $1192.2 \mathrm{~kg}$. The mass fraction of fat in the milk of cows of the Holstein breed of the Hungarian selection was at the level of $4.0 \%$ and higher. The maximum parameter of fat in milk was $4.16 \%$ on average for three lactations obtained from Montvik Chiftain cows and the yield of milk fat was $259.2 \mathrm{~kg}$. Mass fraction of protein in milk on average across all the lines studied by us was within 3.11-3.21\%. The maximum protein content in milk was observed in daughters of bulls of the Reflection of Sovering line in the third lactation $-3.21 \%$.

Table 2: Молочная продуктивность коров по трем лактациям в зависимости от генеалогической принадлежности

\begin{tabular}{|c|c|c|c|c|c|c|c|}
\hline Lactation & $\begin{array}{l}\text { Milk yield for } 305 \\
\text { days, } \mathrm{kg}\end{array}$ & $\begin{array}{c}\text { Mass fraction of } \\
\text { fat, } \%\end{array}$ & Milk fat, $\mathrm{kg}$ & $\begin{array}{l}\text { Mass fraction of } \\
\text { protein, } \%\end{array}$ & Milk protein, kg & Live weight, kg & $\begin{array}{c}\text { Milking } \\
\text { capacity } \\
\text { coefficient, } \mathrm{kg}\end{array}$ \\
\hline \multicolumn{8}{|c|}{ Vis Beck Idiala line $(n=50)$} \\
\hline Second & $6209 \pm 121$ & $4.16 \pm 0.03$ & $257.5 \pm 4.4$ & $3.14 \pm 0.01$ & $196.3 \pm 4.2$ & $530.8 \pm 2.3$ & 1169.3 \\
\hline Third & $7034 \pm 122$ & $3.99 \pm 0.04$ & $280.2 \pm 9.3$ & $3.17 \pm 0.02$ & $215.5 \pm 6.4$ & $551.6 \pm 9.0$ & 1275.2 \\
\hline On the & $6373.7 \pm 113$ & $4.07 \pm 0.03$ & $258.8 \pm 5.6$ & $3.14 \pm 0.08$ & $197.7 \pm 4.6$ & $533.9 \pm 4.9$ & 1192.2 \\
\hline
\end{tabular}




\begin{tabular}{|c|c|c|c|c|c|c|c|}
\hline average & & & & & & & \\
\hline \multicolumn{8}{|c|}{ Montvik Chiftain line $(n=17)$} \\
\hline First & $5529 \pm 383$ & $4.11 \pm 0.04$ & $240.0 \pm 6.4$ & $3.11 \pm 0.01$ & $181.3 \pm 4.8$ & $523.8 \pm 6.2$ & 1055.6 \\
\hline Second & $6096 \pm 159$ & $4.21 \pm 0.04$ & $256.7 \pm 7.3$ & $3.15 \pm 0.01$ & $191.7 \pm 4.7$ & $538.4 \pm 3.9$ & 1140.7 \\
\hline Third & $6787 \pm 119$ & $4.15 \pm 0.04$ & $281.0 \pm 6.2$ & $3.18 \pm 0.02$ & $215.5 \pm 5.5$ & $565.3 \pm 12.0$ & 1200.6 \\
\hline $\begin{array}{c}\text { On the } \\
\text { average }\end{array}$ & $6137.3 \pm 220$ & $4.16 \pm 0.04$ & $259.2 \pm 6.6$ & $3.15 \pm 0.01$ & $196.2 \pm 5.0$ & $542.5 \pm 7.4$ & 1132.3 \\
\hline \multicolumn{8}{|c|}{ Reflection of Sovering line $(n=19)$} \\
\hline First & $5584 \pm 194$ & $4.10 \pm 0.04$ & $240.4 \pm 7.6$ & $3.12 \pm 0.08$ & $183.1 \pm 6.1$ & $516.1 \pm 3.4$ & 1082.0 \\
\hline Second & $6114 \pm 155$ & $4.14 \pm 0.05$ & $252.4 \pm 6.7$ & $3.14 \pm 0.01$ & $192.6 \pm 5.0$ & $557.4 \pm 8.9$ & 1096.9 \\
\hline Third & $7003 \pm 265$ & $4.04 \pm 0.07$ & $283.0 \pm 12.7$ & $3.21 \pm 0.02$ & $224.8 \pm 8.2$ & $568.7 \pm 8.9$ & 1231.4 \\
\hline $\begin{array}{c}\text { On the } \\
\text { average }\end{array}$ & $6233.7 \pm 205$ & $4.09 \pm 0.05$ & $258.6 \pm 9.0$ & $3.16 \pm 0.04$ & $200.2 \pm 6.4$ & $547.4 \pm 7.1$ & 1136.8 \\
\hline
\end{tabular}

The results of studies on the lactation performance of cows for three full lactations showed that the largest amount of milk was got from Vis Beck Idiala cows - $20880.9 \mathrm{~kg}$, which is $3152 \mathrm{~kg}$ or $17.8 \%$ more as compared to the productivity of Montvik Chiftain cows and $1514.8 \mathrm{~kg}$ or $7.8 \%$ more as compared with the productivity of Reflection of Sovering cows (Table 3 ).

Table 3: Lactation performance of cows for three full lactations Vis Beck Idiala line $(\mathrm{n}=50)$

\begin{tabular}{|c|c|c|c|c|}
\hline \multicolumn{5}{|c|}{ Vis Beck Idiala line (n=50) } \\
\hline Milk yield, kg & Fat, \% & $\begin{array}{c}\text { Milk fat, } \\
\mathrm{kg}\end{array}$ & Protein, \% & $\begin{array}{c}\text { Milk } \\
\text { protein, kg }\end{array}$ \\
\hline $20880.9 \pm 869.4$ & $4.01 \pm 3.9$ & $778.3 \pm 56.0$ & $3.15 \pm 0.008$ & $656.9 \pm 26.9$ \\
\hline \multicolumn{5}{|c|}{ Montvik Chiftain line $(\mathrm{n}=17)$} \\
\hline $17728.9 \pm 911.6$ & $4.16 \pm 0.04$ & $687.5 \pm 56.0$ & $3.16 \pm 0.09$ & $559.9 \pm 28.2$ \\
\hline \multicolumn{5}{|c|}{ Reflection of Sovering line (n=19) } \\
\hline $19366.1 \pm 659.9$ & $4.10 \pm 0.04$ & $791.2 \pm 22.9$ & $3.19 \pm 0.04$ & $615.1 \pm 20.7$ \\
\hline
\end{tabular}

The maximum yield of milk fat was obtained from the Reflection of Sovering line - $791.2 \mathrm{~kg}$ and the maximum protein yield due to high productivity was obtained from Vis Beck Idiala cows - 656.9 $\mathrm{kg}$.

In order to study the genetic potential of cows, depending on their origin, we conducted an analysis of lactation performance of mother cows, taking into account their genealogical affiliation (Table 4).

Table 4: Realization of the genetic potential of Hungarian selection cows by the third lactation

\begin{tabular}{|c|c|c|c|c|}
\hline \multicolumn{2}{|c|}{ Parameter } & $\begin{array}{l}\text { Vis Beck } \\
\text { Idiala }\end{array}$ & $\begin{array}{l}\text { Montvik } \\
\text { Chiftain }\end{array}$ & $\begin{array}{l}\text { Reflection } \\
\text { of Sovering }\end{array}$ \\
\hline \multirow{5}{*}{$\begin{array}{l}\text { Parent cow } \\
\text { index - PCI }\end{array}$} & $\begin{array}{c}\text { Milk } \\
\text { yield, kg }\end{array}$ & $8169.4 \pm 353$ & $7775.3 \pm 420$ & $7104.1 \pm 374$ \\
\hline & Fat, \% & $3.68 \pm 0.03$ & $4.04 \pm 0.16$ & $3.91 \pm 0.10$ \\
\hline & $\begin{array}{c}\text { Protein, } \\
\%\end{array}$ & $3.02 \pm 0.05$ & $3.34 \pm 0.06$ & $3.24 \pm 0.07$ \\
\hline & $\begin{array}{l}\text { Milk fat, } \\
\text { kg }\end{array}$ & $300.7 \pm 13.1$ & $321.6 \pm 23.8$ & $275.0 \pm 12.3$ \\
\hline & $\begin{array}{c}\text { Milk } \\
\text { protein, } \\
\text { kg } \\
\end{array}$ & $241.3 \pm 12.9$ & $260.4 \pm 15.3$ & $228.0 \pm 9.5$ \\
\hline \multirow{5}{*}{$\begin{array}{c}\text { Own } \\
\text { productivity }\end{array}$} & $\begin{array}{c}\text { Milk } \\
\text { yield, kg }\end{array}$ & $7034 \pm 122$ & $6787 \pm 119$ & $7003 \pm 265$ \\
\hline & Fat, \% & $3.99 \pm 0.04$ & $4.15 \pm 0.04$ & $4.04 \pm 0.07$ \\
\hline & $\begin{array}{c}\text { Protein, } \\
\%\end{array}$ & $3.17 \pm 0.02$ & $3.18 \pm 0.02$ & $3.21 \pm 0.02$ \\
\hline & $\begin{array}{l}\text { Milk fat, } \\
\text { kg }\end{array}$ & $280.2 \pm 9.3$ & $281.0 \pm 6.2$ & $283.0 \pm 12.7$ \\
\hline & $\begin{array}{c}\text { Milk } \\
\text { protein, } \\
\text { kg }\end{array}$ & $215.5 \pm 6.4$ & $215.5 \pm 5.5$ & $224.8 \pm 8.2$ \\
\hline \multirow{5}{*}{$\begin{array}{l}\text { Realization } \\
\text { of genetic } \\
\text { potential - } \\
\text { RGP }\end{array}$} & $\begin{array}{c}\text { Milk } \\
\text { yield, kg }\end{array}$ & 86.1 & 87.3 & 98.6 \\
\hline & Fat, \% & 108.4 & 102.7 & 103.3 \\
\hline & $\begin{array}{c}\text { Protein, } \\
\%\end{array}$ & 104.9 & 95.2 & 99.1 \\
\hline & $\begin{array}{l}\text { Milk fat, } \\
\text { kg }\end{array}$ & 93.2 & 87.4 & 102.9 \\
\hline & $\begin{array}{c}\text { Milk } \\
\text { protein, } \\
\text { kg }\end{array}$ & 89.3 & 82.8 & 98.6 \\
\hline
\end{tabular}

As a result of the investigations, it was established that the realization of the genetic potential for the third lactation in respect of the milk yield of daughters was within 86.1-98.6\%, in terms of the mass fraction of fat they exceeded mothers and amounted to $102.7-108.4 \%$ and by mass fraction of protein - 95.2-104.9\%.

Physical-chemical parameters of milk of the Holstein cows of the Hungarian selection, which determine the quality of milk, were studied by the second lactation and taking into account the genealogical affiliation. The cows of the Holstein breed of the Hungarian selection had insignificant differences in the physicalchemical parameters of milk. The density was within the normal range and was $1027-1028 \mathrm{~kg} / \mathrm{m}^{3}$, taking into account the genealogical affiliation and the acidity was the same $\left(16^{\circ} \mathrm{T}\right)$.

The maximum amount of dry matter was in the milk of the daughters of the bulls of the Montvik Chiftain and Reflection of Sovering lines - 12.97-12.94\%, including MSNF - 8.51\%, fat content $-4.43-4.46 \%$ and protein $-3.63 \%$ (Table 5).

Table 5: Physical and chemical parameters of cows' milk, depending on genealogical line

\begin{tabular}{|c|c|c|c|}
\hline Parameter & \multicolumn{3}{|c|}{ Genealogical line } \\
\cline { 2 - 4 } & $\begin{array}{c}\text { Montvik } \\
\text { Chiftain }\end{array}$ & $\begin{array}{c}\text { Vis Beck } \\
\text { Idiala }\end{array}$ & $\begin{array}{c}\text { Reflection of } \\
\text { Sovering }\end{array}$ \\
\hline Density, $\mathrm{kg} / \mathrm{m}^{3}$ & $1028 \pm 0.0$ & $1027 \pm 0.0$ & $1028 \pm 0.0$ \\
\hline Acidity, ${ }^{\circ} \mathrm{T}$ & $16 \pm 0.0$ & $16.0 \pm 0.0$ & $16.0 \pm 0.0$ \\
\hline $\begin{array}{c}\text { Mass fraction of fat, } \\
\%\end{array}$ & $4.46 \pm 0.2$ & $4.51 \pm 0.16$ & $4.43 \pm 0.2$ \\
\hline $\begin{array}{c}\text { Mass fraction of } \\
\text { protein, \% }\end{array}$ & $3.63 \pm 0.02$ & $3.03 \pm 0.02$ & $3.63 \pm 0.02$ \\
\hline $\begin{array}{c}\text { Mass fraction of } \\
\text { lactose, \% }\end{array}$ & $4.80 \pm 0.04$ & $4.80 \pm 0.04$ & $4.80 \pm 0.04$ \\
\hline Dry matter, \% & $12.97 \pm 0.02$ & $12.91 \pm 0.03$ & $12.94 \pm 0.01$ \\
\hline MSNF, \% & $8.51 \pm 0.06$ & $8.4 \pm 0.07$ & $8.51 \pm 0.06$ \\
\hline Temperature, ${ }^{\circ} \mathrm{C}$ & $21.5 \pm 0.18$ & $21.4 \pm 0.1$ & $21.5 \pm 0.14$ \\
\hline
\end{tabular}

Note: * - The results are reliable with $\mathrm{P} \geq 0.95 ; * *$ - $\mathrm{P} \geq 0.99$; *** $\mathrm{P} \geq 0.999$

Daughters of bulls of the Vis Beck Idiala line had a maximum butterfat percentage of $4.51 \%$. However, the protein content in the milk of these cows was minimal and amounted to $3.03 \%$.

The economic efficiency of breeding cows of the Hungarian selection was determined taking into account the cost of milk, selling prices and revenues. The level of profitability of milk production for cows of the Hungarian selection was $68.5 \%$.

\section{Discussion}

Holstein cattle is the result of long-term breeding work and is in demand in many countries of the world [9, 11, 12]. When loose housing and balanced feeding, the yield of Holstein cows in the pedigree herds of the Russian Federation reaches 8,000-10,000 $\mathrm{kg}$, and the average yield of Holstein cows in commodity farms are at the level of 6,000-7,000 [1, 2]. The modern dairy type of livestock differs in its economic and biological parameters from the black-and-white type of European countries [22-25]. An important factor in breeding of Holstein cattle is the conditions for increased comfort and the provision of animals with high-quality feed in accordance with the physiological state [3, 7, 8, 29]. 
In order to realize the genetic potential of the black-and-white cows of the Holstein breed of the Hungarian selection, the pedigree breeding unit of Ryazan oblast created comfortable conditions for year-round housing. A continuous-shop technology of milk production was organized at the reconstructed milk complex. The feeding of dairy cows throughout the year was carried out with feed mixtures, taking into account the needs and lactation performance. The control of feeding dairy cattle was carried out on the biochemical parameters of cows' blood.

Black-and-white Holstein cows had economic and biological characteristics, due to age and genealogical affiliation. The Reflection of Sovering cows had the maximum live weight in the third lactation - $568.7 \mathrm{~kg}$. The minimum duration of the service period was for animals of the Vis Beck Idiala line - $152.3 \pm 13.7$ days and the dry period was $55.6 \pm 2.7$ days. Cows belonging to the Montvik Chiftain line had the maximum milk ejection rate of $1.55 \pm 0.22 \mathrm{~kg} / \mathrm{min}$ average for 3 lactations.

For an average of three lactations, the maximum milk yield was obtained from the cows of the Vis Beck Idiala equal to $6,373.7 \mathrm{~kg}$. Cows of this line gave $20,880.9 \mathrm{~kg}$ of milk for three full lactations The maximum yield of milk fat was obtained from the Reflection of Sovering line - $791.2 \mathrm{~kg}$ and the maximum protein yield from the Vis Beck Idiala line was $656.9 \mathrm{~kg}$.

Realization of genetic potential of Holstein cows of the Hungarian selection by the milk yield for the third lactation was within 86.1-98.6 \%, by the mass fraction of fat exceeded the mothers and amounted to $102.7-108.4 \%$ and by the mass fraction of protein it was 95.2-104.9\%.

Physical and chemical parameters of milk were within the normal range and there were no significant differences depending on the genealogical affiliation.

\section{Conclusions}

1. In order to realize the genetic potential of the black-and-white cows of the Holstein breed of the Hungarian selection, the pedigree breeding unit of Ryazan oblast created comfortable conditions for year-round housing. A continuous-shop technology of milk production was organized at the reconstructed milk complex. The feeding of dairy cows throughout the year was carried out with feed mixtures, taking into account the needs and milk production. The control of feeding the dairy cattle was carried out on the biochemical parameters of cows' blood.

2 . The cows had the maximum live weight in the third lactation. The animals of the Reflection of Sovering line were $568.7 \mathrm{~kg}$, which was $17.1 \mathrm{~kg}$ or $3.1 \%$ more as compared to the animals of the Vis Beck Adiala line and $3.4 \mathrm{~kg}$ or $0.6 \%$ as compared to the Montvik Chiftain line.

3. The duration of the dry period was within the physiological norm and was 52.7-63.7 days. The duration of the service period in Holstein cows of the Hungarian selection was relatively high and was within 152.3-181.5 days, the minimum duration was for animals belonging to the Vis Beck Aidiala line 152.3 days.

4. The intensity of milk ejection was at the level of 0.93 $1.76 \mathrm{~kg} / \mathrm{min}$ and increased from the first lactation to the third one by $0.32-0.59 \mathrm{~kg} / \mathrm{min}$ or by $26.6-34.5 \%$. Over the course of three lactations, cows belonging to the Montvik Chiftain line had the best intensity of milk ejection equal to $1.55 \pm 0.22 \mathrm{~kg} / \mathrm{min}$.

5. The study of measurements of the exterior of the Holstein cows showed that they increased with age from the first lactation to the third one. Thus, the height of the cows at the withers in the first lactation was within $138.2-140.4 \mathrm{~cm}$, an average of $138.7 \pm 0.2 \mathrm{~cm}$, and in the third lactation, this parameter increased by $5.7 \mathrm{~cm}$ or $4.1 \%$ and was $144.4 \pm 0.2 \mathrm{~cm}$. Significant differences depending on the genealogical affiliation were not found. The daughters of the bulls of the Montvik Chiftain line had the maximum slanting length of the body in all three lactations and that was $173.2 \pm 0.9-177.9 \pm 1.3 \mathrm{~cm}$. The daughters of the bulls of the Reflection of Sovering line of the second and third lactations had the maximum girth of the breast behind the shoulder blades and that was $192.0 \pm 1.0-193.3 \pm 1.2$ $\mathrm{cm}$.

6. Holstein cows of the Hungarian selection had exterior features due to the age and genealogical affiliation of the cows. The animals belonging to the Reflection of Sovering line had the best commercial-biological traits.

7. The milk production of the Hungarian cows increased from the first to the third lactation by $1,156-1,419 \mathrm{~kg}$ or by $19.7-25.4 \%$. The maximum increase in milk yield on average for three lactations was given by Reflection of Sovering cows and that was $1,419 \mathrm{~kg}$ or $25.4 \%$ higher as compared to the first lactation milk yield.

8. A comparative evaluation of lactation performance of cows, depending on their genealogical affiliation, showed that the maximum lactation performance was obtained from cows of the Vis Beck Idiala line: for the third lactation it was $7,034 \mathrm{~kg}$ with $3.99 \%$ fat content and an average one of three lactations was $6,373.7 \mathrm{~kg}$, and the milk ratio was $1,192.2 \mathrm{~kg}$.

9. The mass fraction of fat in the milk of cows of the Holstein breed of the Hungarian selection was at the level of 4.0 $\%$ and higher. The maximum parameter of fat in milk on average for three lactations was $4.16 \%$ and it was obtained from the Montvik Chiftain cows when the milk fat was $259.2 \mathrm{~kg}$. The maximum yield of milk fat was obtained from the Reflection of Sovering line and that was $791.2 \mathrm{~kg}$.

10. The mass fraction of protein in milk on average across all the lines studied by us was in the range of 3.11-3.21\%. The maximum protein content in milk was observed in daughters of bulls of the Reflection of Shovering line in the third lactation and that was $3.21 \%$. The maximum protein yield due to high productivity was obtained by the Vis Beck Idiala line equal to $656.9 \mathrm{~kg}$.

11. The results of studying the lactation performance of cows for three full lactations showed that the largest amount of milk was obtained from the Vis Beck Idiala cows - 20,880.9 kg, which was $3,152 \mathrm{~kg}$ or $17.8 \%$ more as compared to the performance of the Montvik Chiftain cows and by $1,514.8 \mathrm{~kg}$ or $7.8 \%$ more as compared with the performance of the Vis Beck Idiala cows.

12. The realization of the genetic potential for the third lactation in daughters' milk yield was within 86.1-98.6 \%, in terms of the mass fraction of fat exceeded mothers and was 102.7$108.4 \%$ and by mass fraction of protein it was 95.2-104.9\%.

13. The cows of the Holstein breed of the Hungarian selection had insignificant differences in the physical-chemical parameters of milk. The density was within the normal range and was $1027-1028 \mathrm{~kg} / \mathrm{m}^{3}$, taking into account the genealogical affiliation, the acidity was the same and was $16^{\circ} \mathrm{T}$. The maximum amount of dry matter was in the milk of the daughters of the bulls of the Montvik Chiftain line and the Reflection of Sovering line 12.97-12.94 \%, including MSNF - 8.51\%, fat content - 4.43-4.46 $\%$ and protein $-3.63 \%$. Daughters of bulls of the Vis Beck Idiala line had the maximum butterfat percentage of $4.51 \%$. However, the protein content in the milk of these cows was minimal and amounted to $3.03 \%$.

14. The economic efficiency of breeding cows of the Hungarian selection was determined taking into account the cost of milk, selling prices and revenues. The level of profitability of milk production for cows of the Hungarian selection was $68.5 \%$.

\section{References}

[1] Abylkasymov D., Chargeishvili S.V., Zhuravleva M.E. and Sudarev N.P. (2015). 'Analysis of the cows' productivity parameters in the best dairy herd of Russia', Young Sc., no. 8, pp. 1-4.

[2] Anufriev A.I., Yadrikhinsky V.F. (2017). Changes in body temperature in yakutian breed cows in annual life cycle // Modern Science Success. Vol. 9. № 4. P. 15-20. 
[3] Baymishev M.Kh, Baymishev Kh.B., Zemlyankin V.V., Minyuk L.A., Nechaev A.V. (2017). Prevention of postpartum pathology of drug cimactinum // Modern Science Success. Vol. 9. № 4. P. 7-11.

[4] Baymishev M.Kh, Baymishev Kh.B., Pristyzhnyuk O.N. (2017). Age morphology and growth rate of the ovary and fallopian tubes in heifers black-motley breed // Modern Science Success. Vol. 9. № 4. P. 21-24.

[5] Dunin I.M., Kochetkov A. and Sharkayev V. (2010). 'Breeding and productive qualities of dairy cattle in the Russian Federation', Dairy and Beef Cattle Breeding, no. 8, pp. 2-5.

[6] Byshova N.G. (2011). 'Improving the technology of milk production in connection with the use of innovations', abstr. of dis. of Cand. Agr. S., Ryazan, 19 p.

[7] Izhboldina S.N. and Kudrin M.R. (2015). 'Modern technologies of milk production, contributing to increase the productivity of cows and their longevity', Monograph, Izhevsk, Izhevsk State Agricultural Academy, $168 \mathrm{p}$.

[8] Morozova N.I., Musaev F.A. and Ivanova L.V. (2012). 'Milk productivity of Hungarian cows of the Hungarian selection', Basic res., no. 6, pp. 405-408.

[9] Morozova N.I., Byshova N.G. and Morozova O.A. (2016). 'Milk productivity of Holstein cows at breeding plant "Avangard" when balancing diets in the "Feed Optima Expert" program', Herald of RSATU, no. 3, pp. 32-37.

[10] Morozova N.I., Musaev F.A. and Ivanova L.V. (2011). 'Technology of milk production and primary processing at a reconstructed complex', Herald of RSATU, no. 4, pp. 27-29.

[11] Sudarev N.P. and Sharkaev D.A. (2016). 'Breeding the Holstein and black-and-white cattle at farms of Russia, the Central federal district and Tver oblast', Zootech., no. 3, pp. 2-4.

[12] Strekozov N.I. (2008). 'Dairy cattle breeding of Russia, the present and the future', Zootech., no. 1, pp. 18-21.

[13] Tunikov G.M. and Pavlyukhin A.M. (1995). 'Problems of cows' longevity and factors causing it', Coll. of sc. works of Ryazan SAA, Ryazan, pp. 40-42.

[14] Tunikov G.M., Starodumov I.M. and Pavlyukhin A.M. (2001). 'The influence of some factors on the duration of commercial use of cows of different breeds in Ryazan oblast', Conf. proceed. of Ryazan St. Agr. Acad., Ryazan, pp. 158-160.

[15] Tunikov G.M. and Korovushkin A.A. (2004). 'Genetic markers of longevity', Coll. of sc. works of Ryazan St. Agr. Acad., Ryazan, pp. $60-61$.

[16] Tunikov G.M., Byshova N.G. and Ivanova L.V. (2011). 'Rational techniques in feeding Holstein cows when loose housing', Zootech., no. 4 , pp. 16-17.

[17] Ansell R.H. (1974). 'Observations on the reaction of British Friesian cattle to the lugnt ambient temperatures of the United Arab Emirates', University of Bern. Thesis, pp. 30-38.

[18] Benleknal A. (1985). 'Reporte del Programa en Marruecos', Documentopresenta do alaconculta FAO de expertossobre I.A. Traspl. De Embriones. Roma, pp. 9-12.

[19] Johnson R.A. and Bhattacharya G.K. (2010). 'Statistics Principles and Methods', 6th ed., Hoboken, NJ, USA, John Wiley \& Sons, Inc.

[20] Hammak S.P. (2003). 'Creating cattle breeds and composites', College Station Texas, Texas Coop. Extens., Texas, A. M. University.

[21] Kliwer R.H. (1982). 'Computer management of Breedinog Plans and optional matting of dairy cattle', A.R.S. Genetics. Ins. Vernom, USA, p. 15

[22] Lin C.Y. and Togashi K. (2005). 'Maximization of Lactation Milk Production. Without Decreasing. Persistency', J. Dairy Sci. 88: 2975-2980, Am. Dairy Sc. Assoc.

[23] Lindstrom U.B. (2006). 'Utilizing animal gene resources', World animal review, http: //www. Fao. Org. / DOCREP / 004 /X 6500 E / X 6500 E04. ytm.

[24] Prescott M.S., Scholl M., Wing H.H. and Holste W.A. (1960) 'Holste in-Friesian History, HFA', $551 \mathrm{p}$.

[25] Mansfield R.H. (1985). 'Progress of the Breed', The History of U.S. Holsteins, 348 p.

[26] McDowell R.E. (1974). 'Annual progress report to the echnical Committee', Nov. 1973 - Oct. 1974.

[27] Miglior F., Muir B.L. and Van Doormaal B.J. (2005). 'Selection Indices in Holstein Cattle of Various Countries', Am. Dairy Sc. Assoc., J. Dairy Sci., pp. 1255-1263.

[28] Melendez P. and Pinedo P. (2007). 'The association between reproductive performance and milk yeld in Chilean Holstein cattle', J. Dairy Sci., vol. 90, no. 1, pp. 184- 192.
[29] Schiller R., Vakhal Y.A. and Finsh Y.A. (1981). 'Selection in animals breeding practice', Moscow, USSR, Kolos.

[30] Jasioravski H., Reklewski Z. and Stolzman S. (1983). 'Testing of different strains of friesian cattle in Poland', Livestock Prod. Sci., no. 2, pp. 109-122.

[31] Johansson, J. (2004). 'Genetic aspects of dairy cattle breeding', Univ.of Illinois, Press. 'Do You Know This About Holstein Cattle?', http://www.holsteinusa.com/pdf/fact_sheet_cattle.pdf 